BMJ Open Sport \& Exercise Medicine

\section{Physical preparation and return to sport of the football player with a tibia-fibula fracture: applying the 'control- chaos continuum'}

To cite: Taberner M, van Dyk N, Allen T, et al. Physical preparation and return to sport of the football player with a tibia-fibula fracture: applying the 'control-chaos continuum'. BMJ Open Sport \& Exercise Medicine 2019;5:e000639. doi:10.1136/ bmjsem-2019-000639

- Additional material is published online only. To view please visit the journal online (http://dx.doi.org/10.1136/ bmisem-2019-000639).
Check for updates

(C) Author(s) (or their employer(s)) 2019. Re-use permitted under CC BY-NC. No commercial re-use. See rights and permissions. Published by BMJ.

For numbered affiliations see end of article.

Correspondence to Mr Matt Taberner; matthewtaberner@btinternet. com

\section{ABSTRACT}

Contact in elite football can result in severe injury such as traumatic fracture. Limited information exists regarding the rehabilitation and return to sport (RTS) of these injuries especially in elite football. We outline the RTS of an elite English Premier League footballer following a tibia-fibula fracture including gym-based physical preparation and the use of 'control-chaos continuum' as a framework for on-pitch sport-specific conditioning, development of technical skills while returning the player to pre-injury chronic running loads considering the qualitative nature of movement in competition. Strength and power diagnostics were used to back up clinical reasoning and decisionmaking throughout rehabilitation and the RTS process. The player returned to full team training after 7.5 months, completed 90 min match-play after 9 months and remains injury-free 11 months post-RTS.

\section{CASE SCENARIO}

While non-contact lower limb injuries are common in elite football, ${ }^{1}$ contact from poorly timed kicks or tackles can result in severe injuries such as traumatic fracture. Currently, limited information exists describing the rehabilitation and the Return to Sport (RTS) following traumatic fractures (commonly to the tibia, fibula or a combination of both).$^{23}$

In this video-supported viewpoint, we outline the on-pitch/sport-specific rehabilitation of an English Premier League footballer who suffered an open fracture of the distal tibia-fibula just above the ankle joint following an opponent's poorly timed kick (figure 1A). Using the 'control-chaos continuum' as a framework for RTS, ${ }^{4}$ the goal was to return the player to pre-injury running loads using global positioning systems (GPS). The qualitative aspects of movement in competition were also considered; progressive variable, spontaneous and unanticipated movements, (the conditions of chaos) reflecting the unpredictable nature of sport. ${ }^{4}$

\section{Key points}

Progressive mechanical loading designed to restore mechanical rigidity is the foundation for return to running following traumatic fracture.

- The 'control-chaos continuum' is an adaptable framework to provide progressive sport-specific conditioning, integration of technical skills and returning players to chronic (pre-injury) running loads considering the qualitative nature of movement in competition.

- Strength and power diagnostic testing support clinical reasoning and decision-making throughout rehabilitation and return to sport (RTS).

- Communication and shared decision-making are essential for optimal player care during RTS.

\section{MECHANICAL LOADING: THE FOUNDATION FOR RETURN TO RUNNING}

Early management following surgery was aimed at optimal loading to minimise muscle atrophy and to regain pain-free full range of motion (table 1). Optimal loading may be defined as the load applied to structures that maximises physiological adaptation and restores function. ${ }^{5}$ Throughout rehabilitation, conditioning was designed to restore mechanical rigidity by applying progressive loading to stimulate bone remodelling based on the principles of mechanotransduction. ${ }^{6}$

A variety of isometric exercises (figure 2) were used to develop strength in key running-specific positions, such as the initial acceleration and stance phases. Additionally, dynamic hip and knee flexor/extensor exercises (figure 2) were used to provide greater loading stimulus for bone adaptation. ${ }^{7}$ Blood flow restriction was implemented on selected exercises (figure 2) to enhance local growth factor release, stimulate bone remodelling and cross-sectional hypertrophy of the involved limb. ${ }^{8}$ We integrated jump-landing activities progressively, to develop the player's 

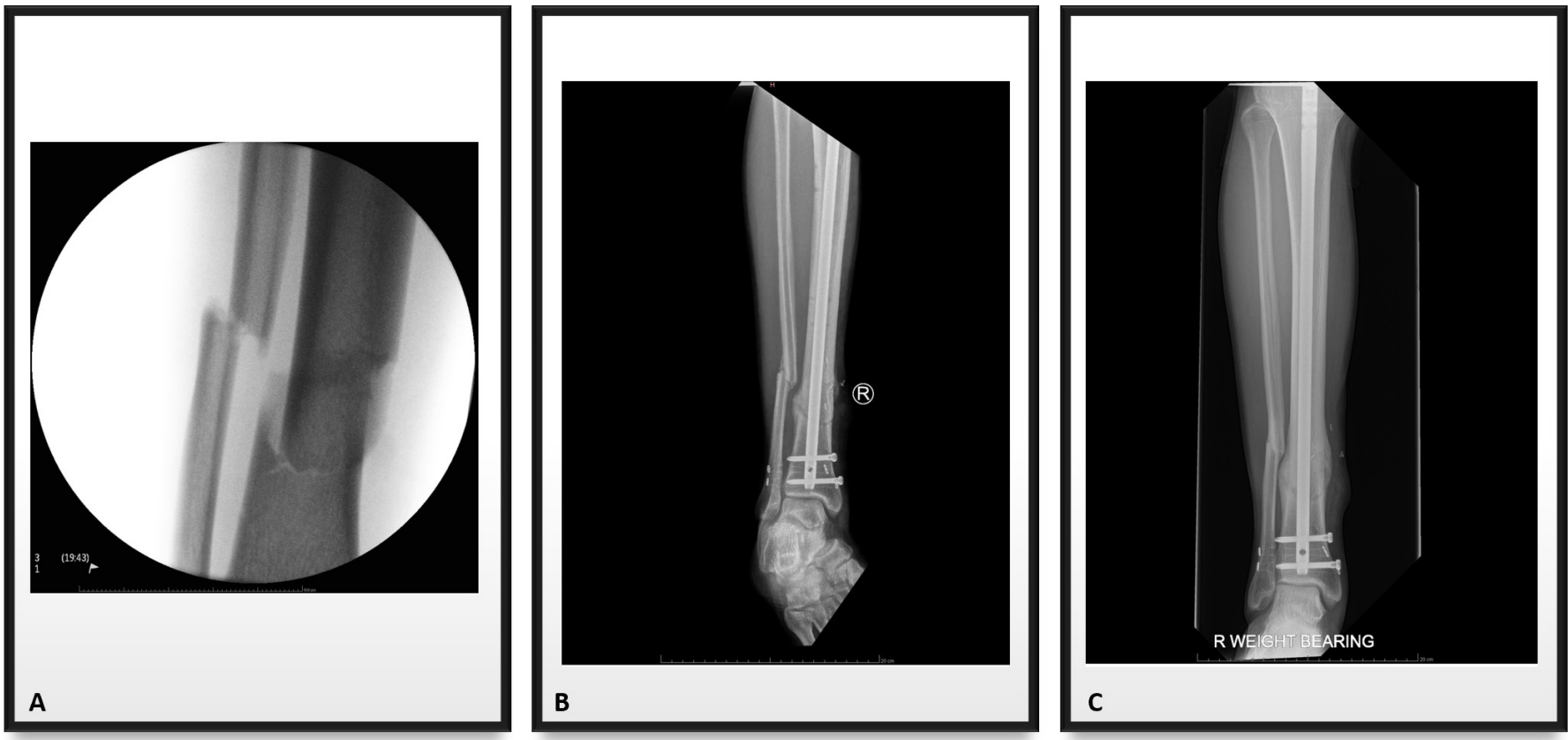

Figure 1 Radiology: (A) Intra-operative image of a tibia-fibula fracture following a poorly timed kick in an English premier League match. (B) X-ray image of remodelling tibia-fibula fracture (15-week post-injury). (C) X-ray image of full union following tibia-fibula fracture (28-weeks post-injury).

capacity to produce and accept force at high velocity, moving from in-place/slow stretch-shortening cycle (SSC) activities to increasingly dynamic fast SSC activities (figure 2). ${ }^{9}$

Fifteen weeks post-injury, the fracture site had virtually united (figure 1B). Additionally, with strength diagnostics (isometric posterior chain and isometric mid-thigh pull) within $<10 \%$ peak force limb asymmetry, the player had achieved criteria to initiate anti-gravity treadmill running (Alter-G, Fremont, USA). The player began running at $60 \%$ bodyweight, progressing to $90 \%$ as the penultimate step before transition to on-pitch running, five months post-injury.

\section{RTS USING THE 'CONTROL-CHAOS CONTINUUM'}

When formulating the on-pitch running programme, we emphasised gradual progression in both volume and intensity, creating progressive increments in load - key bone remodelling stimuli. ${ }^{9}$ We extended the return to running phase and progressively introduced high-speed running (HSR), relative to training/match demands implementing twoweek progressive increments in running loads followed by a one week reduction until the desired loads were achieved. ${ }^{4}$ Throughout rehabilitation, physical conditioning emphasised the development of aerobic-alactic fitness, repeated accelerations and speedendurance qualities. Daily communication between the performance, medical team and player was integral throughout the process with minimal pain $(<2 / 10$ numerical rating scale), absence of joint effusion, achievement of running load targets and technical actions as phase progression criteria.

\section{HIGH CONTROL: WEEKS 1-3 (20-23 WEEKS POST-INJURY)}

The high control phase aimed to establish a base for on-pitch preparation, and to progressively increase running volume (total distance). Running speeds were limited to $60 \%-65 \%$ of maximal speed to limit strain rate and magnitude of bone loading. Return to running sessions comprised of box-to-box runs; walking to the edge of the 6-yard box and back as active recovery (figure 3). This phase laid the foundation for running progression and built player confidence and trust in the rehabilitation process.

\section{MODERATE CONTROL: WEEKS 4-6 (24-26 WEEKS POST- INJURY)}

Having set the foundation, the aim of this stage was to reduce task and environmental constraints, ${ }^{10}$ while progressively increasing explosive distance. Change of direction was incorporated into intermittent dribbling lanes while slightly increasing linear running velocities to achieve lower threshold HSR ('zone 5'; between $5.5 \mathrm{~ms}^{-1}$ and $7 \mathrm{~ms}^{-1}$ ). These HSR efforts were integrated over distances of $40 \mathrm{~m}$ with gradual acceleration and decelerations, hence over the $40 \mathrm{~m}$, only $20-25 \mathrm{~m}$ lower threshold HSR was achieved, with the number of these efforts tailored to sessional running load targets. Within these sessions, technical qualities such as short-range passing (figure 3) were added, but in a controlled manner, ie, $5 \mathrm{~m}$ pass to rebound board, as part of intermittent conditioning blocks. Low volume contact was also integrated (ie, static block tackle; $2 \times 2$ repetitions), targeting the involved limb to create site-specific mechanical loading stimuli. ${ }^{11}$ Conditioning aimed to develop threshold 


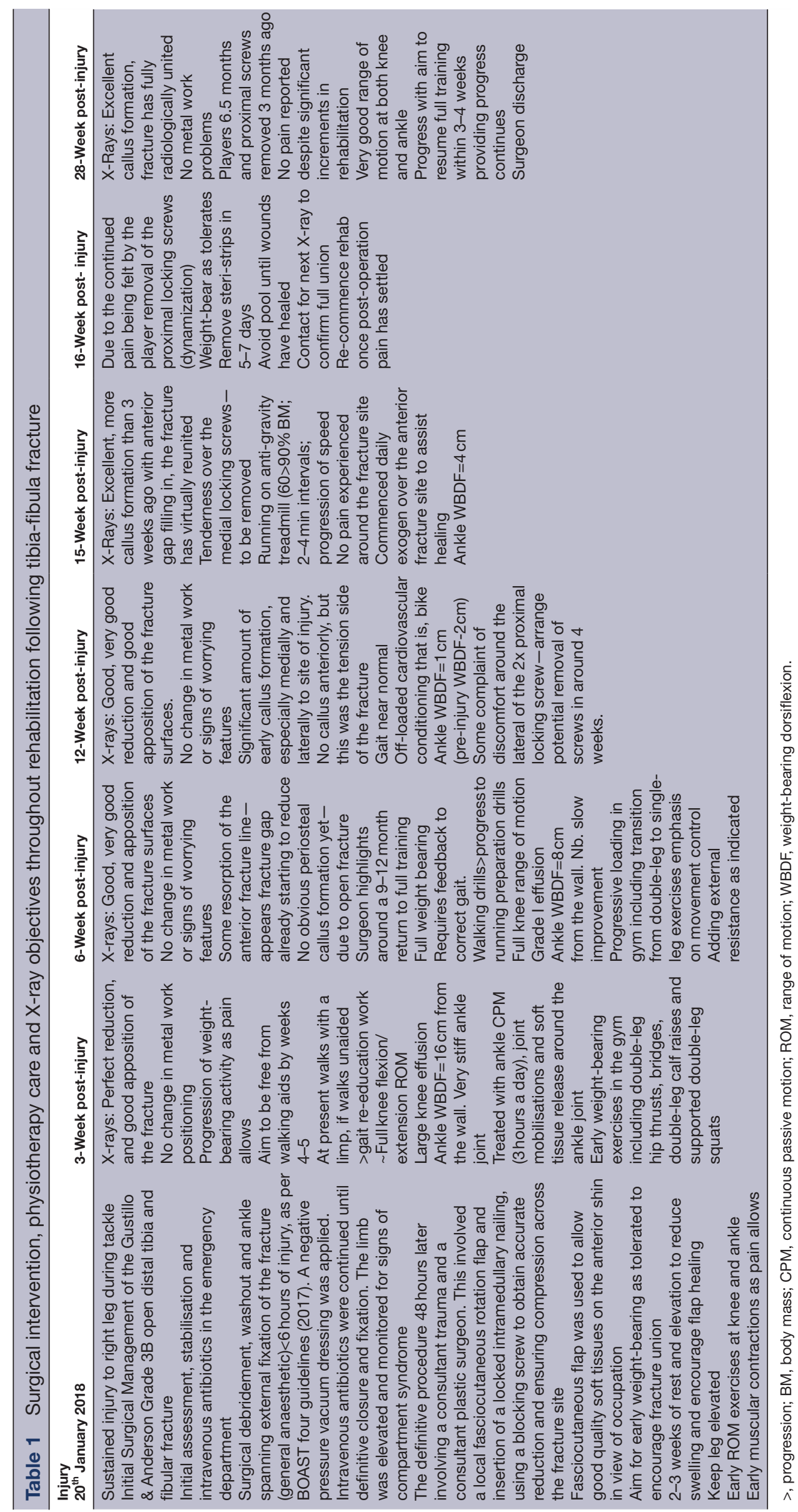




\begin{tabular}{|c|c|c|c|c|c|c|c|c|c|c|c|c|}
\hline \multicolumn{2}{|c|}{ ISOMETRIC STRENGTH } & \multicolumn{4}{|c|}{ JUMP-LANDING PREPARATION } & \multicolumn{4}{|c|}{ DYNAMIC STRENGTH } & BFR $^{*}$ & \multicolumn{2}{|c|}{ ACGESSORY STRENGIH } \\
\hline \multirow{2}{*}{$\begin{array}{l}\text { SL. Iso Heel Drives } \\
\left(30^{\circ} / 90^{\circ}\right)\end{array}$} & \multirow{2}{*}{$\begin{array}{l}\text { DL Iso Hip } \\
\text { Extension } \\
\text { (>load) }\end{array}$} & $\begin{array}{l}\text { In-place } \\
\text { extension }\end{array}$ & $\begin{array}{l}\text { Box Jump } \\
\text { (?height) }\end{array}$ & Hurdle Jumps & $\begin{array}{l}\text { Hurdle Jumps } \\
\text { (>reps/height/ } \\
\text { distance) }\end{array}$ & $\begin{array}{l}\text { Posterior: } \\
\text { Hip Dom }\end{array}$ & $\begin{array}{l}\text { Posterior: } \\
\text { Knee Dom }\end{array}$ & $\begin{array}{l}\text { Anterior/Posteri } \\
\text { or: } \\
\text { Hip/knee Hybrid } \\
\text { (STR-Neural) }\end{array}$ & $\begin{array}{l}\text { Anterior/Posteri } \\
\text { or: } \\
\text { Hip/knee hybrid } \\
\text { (STR-CSA) }\end{array}$ & $\begin{array}{l}\text { Anterior/Posteri } \\
\text { or: } \\
\text { Knee } \\
\text { Extensors/Ankle } \\
\text { Plantar flexors } \\
\text { (STR-CSA) }\end{array}$ & $\begin{array}{l}\text { Hip Strength: } \\
\text { Adduction bias }\end{array}$ & $\begin{array}{l}\text { Hip Strength: } \\
\text { Abduction bias }\end{array}$ \\
\hline & & Drop Squat & $\begin{array}{l}\text { SL Box Jump } \\
\text { (>height) }\end{array}$ & Hurdle Hops & $\begin{array}{l}\text { Hurdle Hops } \\
\text { (>reps/distance) }\end{array}$ & $\begin{array}{c}\text { Hip Thrust } \\
\text { (>load) }\end{array}$ & $\begin{array}{l}\text { Sliding Leg Curl } \\
\text { (Ecc only) }\end{array}$ & DB Step-Up & $\begin{array}{c}\text { TRX Supported } \\
\text { Split Squat }\end{array}$ & $\begin{array}{l}\text { Supported Split } \\
\text { Squat }\end{array}$ & $\begin{array}{c}\text { MB Crush } \\
\text { (various } \\
\text { positions- } \\
\text { ssometric) }\end{array}$ & Side Lying Clam \\
\hline $\begin{array}{l}\text { SL Mid-stance Iso } \\
\text { Push }\end{array}$ & \multirow{3}{*}{$\begin{array}{l}\text { SL Iso Hip } \\
\text { Exxension } \\
\text { (>load) }\end{array}$} & $\begin{array}{l}\text { Drop Squat } \\
\text { 'Catch' }\end{array}$ & $\begin{array}{l}\text { DL Altitude Drop } \\
\text { Landings }\end{array}$ & $\begin{array}{c}\text { Hurdle Jump > } \\
\text { Box Jump }\end{array}$ & $\begin{array}{l}\text { SL Lat/Med Box } \\
\text { Jumps }\end{array}$ & \multirow{3}{*}{$\begin{array}{l}\text { Pull Through } \\
\text { (>load) }\end{array}$} & $\begin{array}{l}\text { Sliding Leg Curl } \\
\text { (Con:Ecc) }\end{array}$ & Barbell Step-Up & $\begin{array}{l}\text { TRX Supported } \\
\text { Split Squat } \\
\text { (Paused Rep: } \\
\text { 3-5s) }\end{array}$ & Split Squat & $\begin{array}{l}\text { Side Lying } \\
\text { Adductor Lifts } \\
\text { (Dynamic) }\end{array}$ & Band Walks \\
\hline $\begin{array}{l}\text { SL Toe-off Iso } \\
\text { Push }\end{array}$ & & $\begin{array}{l}\text { Split Stance } \\
\text { Drop Squat }\end{array}$ & $\begin{array}{c}\text { Split Stance } \\
\text { Drop Landings }\end{array}$ & \multirow{3}{*}{$\begin{array}{l}\text { Hurdle Hops > SL } \\
\text { Box Jump }\end{array}$} & $\begin{array}{l}\text { SL Lat/Med } \\
\text { Hurdle Hops } \\
\text { (>reps) }\end{array}$ & & $\begin{array}{l}\text { Sliding Leg Curl } \\
\text { (distal load) }\end{array}$ & $\begin{array}{l}\text { Barbell Step-up } \\
\text { (>box height) }\end{array}$ & $\begin{array}{l}\text { Supported Split } \\
\text { Squat } \\
\text { (Proximal load) }\end{array}$ & $\begin{array}{c}\text { Supported Calf } \\
\text { Raise }\end{array}$ & $\begin{array}{l}\text { Short-Lever } \\
\text { Copenhagen's } \\
\text { (Isometric) }\end{array}$ & $\begin{array}{l}\text { Split Stance } \\
\text { Band Walks }\end{array}$ \\
\hline Iso Split Squat & & $\begin{array}{l}\text { Split Stance } \\
\text { Drop Squat } \\
\text { 'Catch' }\end{array}$ & \multirow{2}{*}{$\begin{array}{l}\text { SL Drop } \\
\text { Landings }\end{array}$} & & \multirow{3}{*}{$\begin{array}{l}\text { SL Drop Jump > } \\
\text { Hurdle Hops } \\
\text { (>height/reps) }\end{array}$} & & $\begin{array}{l}\text { Sliding Leg Curl } \\
\text { (variable } \\
\text { resistance) }\end{array}$ & $\begin{array}{l}\text { Barbell Step-Up } \\
\text { (variable- } \\
\text { resistance-band } \\
\text { resisted) }\end{array}$ & $\begin{array}{l}\text { Supported Split } \\
\text { Squat } \\
\text { (Paused rep- } \\
\text { Proximal Load) }\end{array}$ & $\begin{array}{l}\text { Supported } \\
\text { Single-Leg Calf } \\
\text { Raise }\end{array}$ & $\begin{array}{l}\text { Short-lever Hip } \\
\text { Lifts } \\
\text { (Dynamic) }\end{array}$ & $\begin{array}{l}\text { Single-leg/split } \\
\text { Stance Squat } \\
\text { Variations }\end{array}$ \\
\hline \multirow{3}{*}{\multicolumn{2}{|c|}{$\begin{array}{l}>70 \% \mathrm{MVCC} 3-5 \times 55(5 \mathrm{~s}) \\
\text { Nb. Overload to injury side e.g. } 3 / 2 \text { or } \\
\text { 4/2 dependant upon asymmetry/specific } \\
\text { requirements }\end{array}$}} & $\begin{array}{l}\text { SL Drop Squat } \\
\text { 'Catch' }\end{array}$ & & & & \multicolumn{7}{|c|}{ 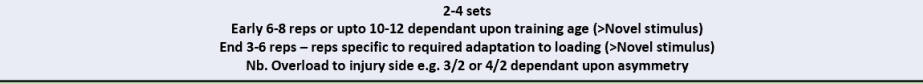 } \\
\hline & & 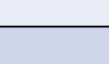 & & & & \multicolumn{7}{|c|}{ 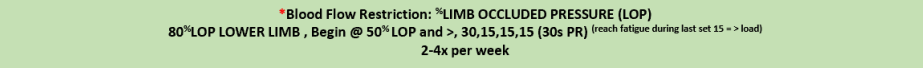 } \\
\hline & & B & $\begin{array}{l}\text { ury side e.g.3/2 or } \\
\text { requi } \\
\text { ination based upor }\end{array}$ & $\begin{array}{l}\text { dependant upon } \\
\text { nents } \\
\text { |uality of moveme }\end{array}$ & ymmetry/specitic & C & & Dynamic-1 & $\begin{array}{l}2-4 \text { sets } \\
\text { metric }-2-3 \times 3-20-3 c \\
15 \text { reps or } 10 y d s \text { (wa }\end{array}$ & s variations) & & \\
\hline
\end{tabular}

Figure 2 Exercise selection following a tibia-fibula fracture. (A) Progression of isometric strength exercise selection.

Overcoming=pushing/pulling against an immovable object, Yielding=holding a weight, and preventing it from moving (fixed position) that is, resistance to deformity. (B) Progression of jump-landing exercise selection. Moving from slow SSC and inplace to fast SSC, dynamic activities. (C) Progression of dynamic strength exercise selection. BFR, blood flow restriction; Con, concentric; CSA, cross-sectional area; CT, contact time; Early, early rehabilitation phase; DB, dumbbells; DL, double leg; Ecc, eccentric; End, end rehabilitation phase; hip dom, hip dominant; Iso, isometric; knee dom, knee dominant, Lat, lateral; MB, medicine ball; Med, medial; MVC, maximal voluntary contraction; Novel, novel load, providing a novel stimulus for bone remodelling; PR, passive recovery; reps, repetitions; s, seconds; SL, single-leg; SSC, stretch-shortening cycle; STR, strength; $>$, progression.

endurance $\quad\left(80 \%-90 \%\right.$ maximal heart-rate $\left(\operatorname{Max}^{\mathrm{HR}}\right)$; figure 3), with volume progressed by increasing the number of $3-4 \mathrm{~min}$ intervals and alterations in session density by manipulating rest periods (1-2 min passive recovery). Throughout this phase, we increased total distance, with the intensity of the drill and high metabolic load distances manipulated by altering work to rest ratio between intermittent efforts (per interval).

\section{CONTROL TO CHAOS: WEEKS 7 AND 8 (27-28 WEEKS POST- INJURY)}

Following a reduction in running loads during week six (session number reduced from four to three), week seven saw the transition to a football-specific model with either intensive or extensive sessions (figure 3$).{ }^{4}$ Intensive sessions integrated technical qualities through the inclusion of pass and move drills with other staff involved to increase the 'chaotic' demands of the session while maintaining control over the number, distance and direction of passing. Additionally, positional acceleration drills were integrated during intensive sessions to target acceleration/deceleration qualities important to the nature of the players position (2-3 sets; 3-6 repetitions; $\sim 5 \mathrm{~m})$. Positional-specific conditioning drills were also performed in areas specific to the player's training/ match demands. We designed warm-ups according to the specific demands of the session, ie, for extensive sessions higher speeds and longer distances. Extensive conditioning drills were designed to achieve planned HSR targets determined by current rehabilitation HSR, chronic HSR targets and the players game load. If these targets were not achieved, additional HSR was performed using aerobic power (15:15 s) intervals $(85 \%-$ $90 \% \mathrm{Max}^{\mathrm{HR}} ; \sim 40-45 \mathrm{~m}$ HSR per repetition) (figure 3 ).

\section{MODERATE CHAOS: WEEKS 9 AND 10 (29-30 WEEKS POST- INJURY)}

Intensive and extensive sessions were designed to continue the development of aerobic fitness $(>85 \%$ $\mathrm{Max}^{\mathrm{HR}}$ ) with the speed/direction of passing used to dictate player movement within football-specific conditional drills. Using GPS metrics, chronic loading was aligned with pre-injury training load while we increased the volume of technical actions such as, block tackling ( $4 \times 3$ repetitions); with consideration given to matchplay context (ie, number of block challenges). Within extensive sessions, we increased moderate to long-range passing with an emphasis on the player moving to receive the ball in a suitable position to deliver a pass, such as a diagonal cross-field pass before transitioning up the field of play (generating HSR) to receive the ball in the final third of the field - emphasising speed-endurance conditioning (figure 3). At twenty-eight weeks post-injury, 

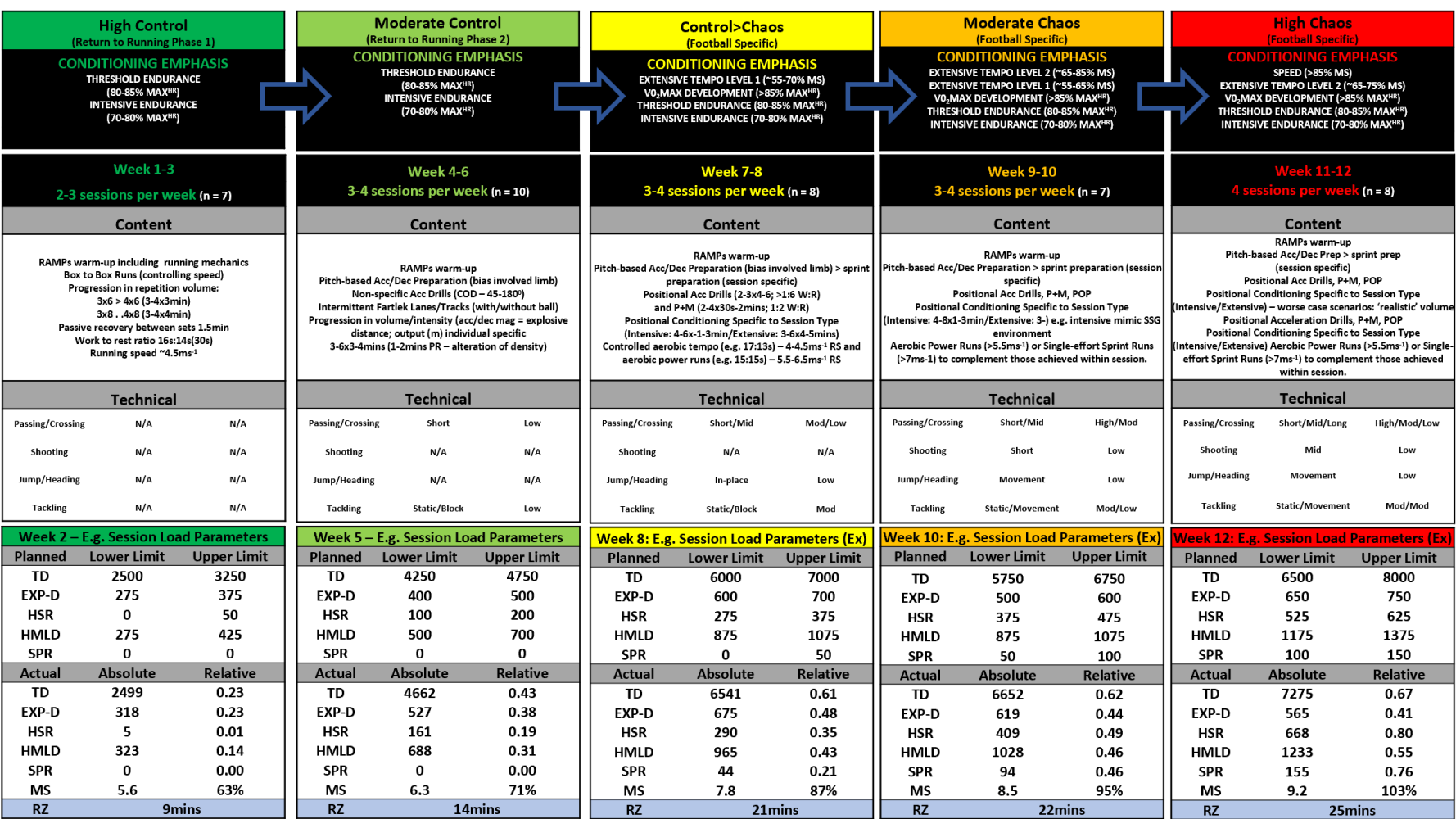

Figure 3 Example 'control-chaos continuum' phase progression content including conditioning emphasis, no. of sessions, technical qualities and actual session running load targets (upper, lower and actual values). Control=high influence on behaviour/actions/movement, that is, controlled situation. Chaos=behaviour/actions/movement that is unpredictable as to appear random/reactive, that is, chaotic situation. Green represents high control (low intensity) moving towards high chaos (high intensity). Model can be adjusted specific to injury diagnosis, estimated tissue healing times and expected return to training. TD, total distance; HSR, high-speed running $\left(>5.5 \mathrm{~ms}^{-1}\right)$, SPR, sprint distance $\left(>7 \mathrm{~ms}^{-1}\right)$, Exp-D, explosive distance (accelerating/decelerating from 2 to $4 \mathrm{~ms}^{-1}<1 \mathrm{~s}$ ), HMLD, high metabolic distance (distance above $25 \mathrm{w} . \mathrm{kg}^{-1}$; sum of HSR and EXP-D), Acc, accelerations; Dec, decelerations, magnitude (Acc/Dec), rate of change in velocity, for example, 3ms ${ }^{-2}$, PR, passive recovery; COD, change of direction, BW, bodyweight; MS, maximal speed; MAX ${ }^{\mathrm{HR}}$, maximal heart rate; RZ, red zone $\left(>85 \% \mathrm{Max}^{\mathrm{HR}}\right),{ }^{* *}=$ gameload adjustable dependent on injury specificity/severity, SSG, small-sided games, 'realistic'=real-life representation of the volumes (distances/durations) the player is exposed to during training/match-play. Ex, extensive session example, RAMPs, raise; elevate heart rate, Activate, activate key muscles groups involved in activity, Mobilise=mobilise key joints involved during activity, Potentiate=potentiate the neuromuscular system for activity, Specific=relevance of other acronyms in relation to the players actual sport/specific training session type; $n$, number of sessions within each phase.

the fracture site was united (figure 1C) and the player discharged from surgical care.

\section{HIGH CHAOS (WEEKS 11 AND 12 (31-32 WEEKS POST-INJURY)}

In the final two weeks of rehabilitation, chronic load was increased above pre-injury training load but just below concurrent (training plus match) load given player was to be phased back into team training before competitive match involvement (figure 4). We continued to emphasise aerobic conditioning with session internal load (heart-rate exertion and time $>85 \% \mathrm{Max}^{\mathrm{HR}}$ ) dictated by drills aiming to mimic training structure. Increased HSR $\left(>5.5 \mathrm{~ms}^{-1}\right)$ and sprinting $\left(>7 \mathrm{~ms}^{-1}\right)$ volume was achieved by chaotically moving onto through balls, and predominantly through speed and speed-endurance conditioning drills (figure 3). If session targets were not achieved, additional sprint distance was performed through rolling single-effort sprints $(40 \mathrm{~m}$ in $5-6 \mathrm{~s} ; \sim 20-25 \mathrm{~m}$ sprint distance). During the final week of rehabilitation, the player achieved a new maximal speed $\left(9.2 \mathrm{~ms}^{-1}\right.$;
$103 \%$ pre-injury) (figure 3). The player returned to training after seven months, although jump height and its principle determinant (Con impulse) was still below pre-injury values, key countermovement jump (CMJ) neuromuscular efficiency (flight time:contraction time), eccentric capacity (Ecc. Decel. RFD) and early force production markers (Con Impulse-100ms) had returned to or were superior to pre-injury values (figure 5). Importantly, key force reduction (Ecc. Decel RFD) and production (Peak Con GRF) CMJ asymmetries, identified as showing persistent deficits following severe injury in elite players even after return to competition, ${ }^{12}$ were close to zero. After ninemonths, the player completed 90 min of competitive match-play, and currently remains injury-free eleven month post-RTS having been everpresent during team training and available for selection as required by team management. 


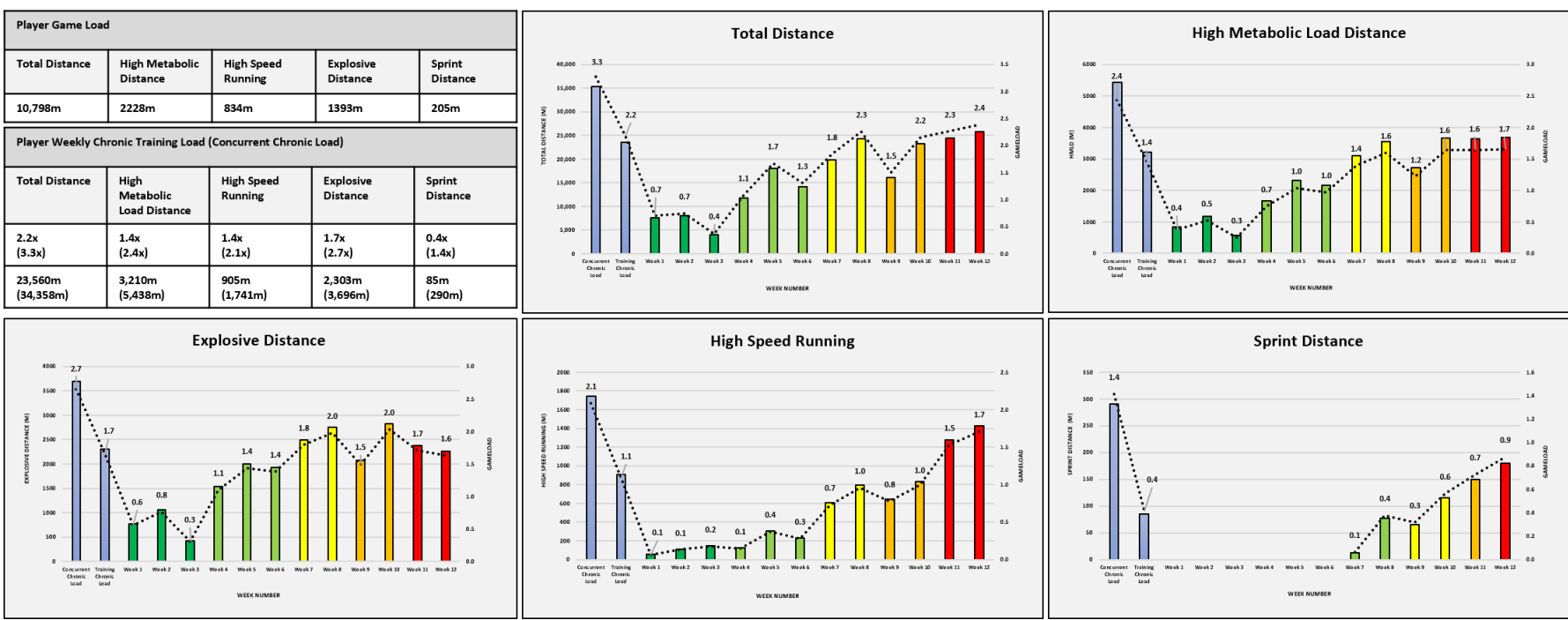

Figure 4 Return to chronic running loads following tibia-fibula fracture using the 'control-chaos continuum' as a framework for return to sport. Data representative game load, that is, physical demands of game (mean) and respective training and concurrent (including match) in both absolute and relative (gameload, ie, 2x=2 games). TD, total distance; HSR, high-speed running $\left(>5.5 \mathrm{~ms}^{-1}\right)$, SPR, sprint distance $\left(>7 \mathrm{~ms}^{-1}\right)$, Exp-D, explosive distance (accelerating/decelerating from 2 to $4 \mathrm{~ms}^{-1}<1 \mathrm{~s}$ ), HMLD, high metabolic distance (distance above $25 \mathrm{w} \cdot \mathrm{kg}^{-1}$; sum of HSR and EXP-D). Control-chaos continuum: Control, high influence on behaviour/actions/movement, that is, controlled situation. Chaos, behaviour/actions/movement, that is, unpredictable as to appear random/reactive, that is, chaotic situation. Green represents high control (low intensity) moving towards high chaos (high intensity). Global positioning systems (augmented $10 \mathrm{~Hz}$ Apex, Statsports, Belfast, UK).
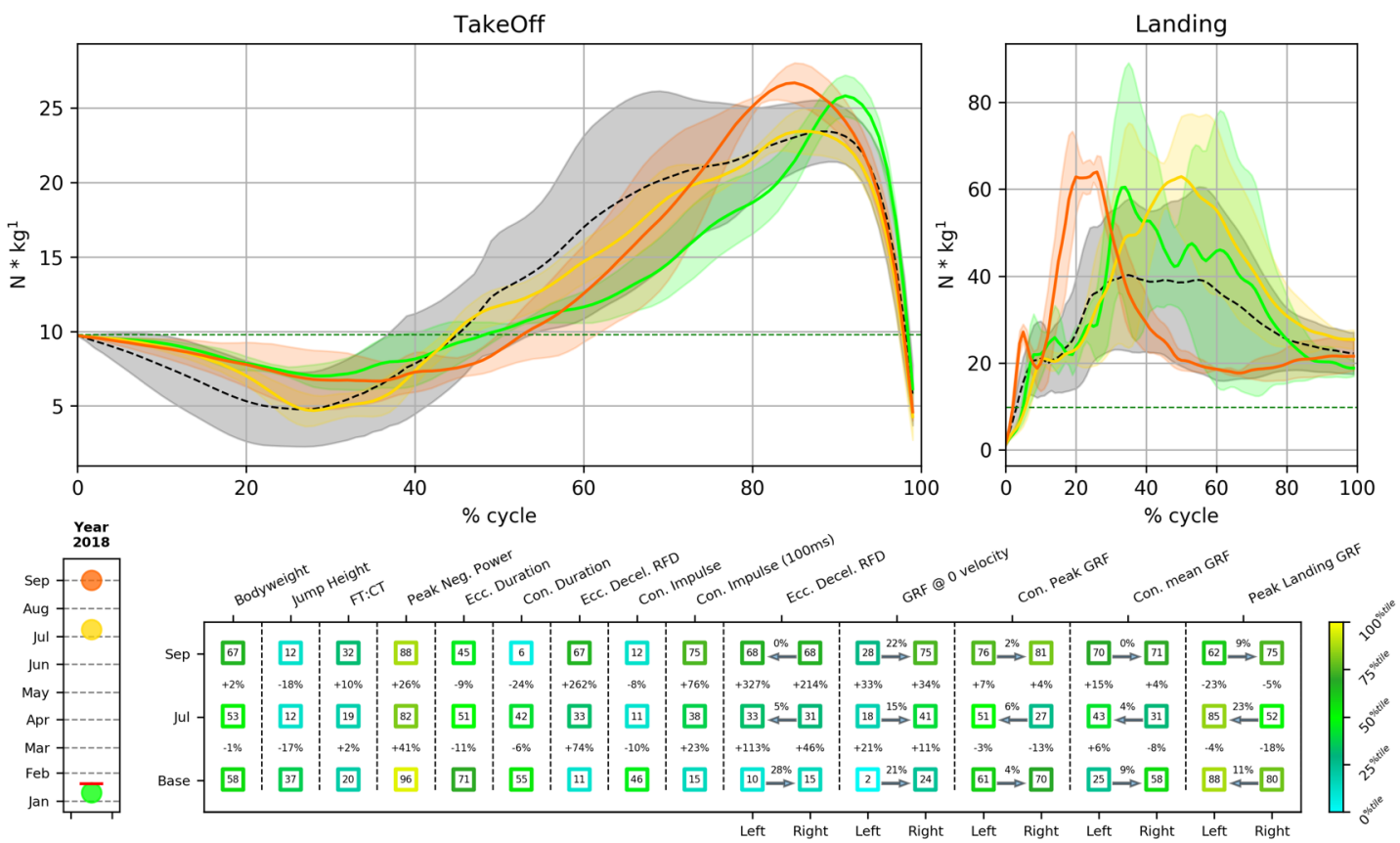

Figure 5 Changes in selected Countermovement Jump (CMJ) bilateral and unilateral variables, asymmetries and force-time curves in January (pre-injury), in July (first CMJ evaluation during rehabilitation) and in September (prior to return to training). Upper panels shows mean force-time curves (trials) normalised for time during take-off ( $0=$ start of movement, $100 \%=$ take off) and landing ( $0=$ landing, $100 \%=$ the end of eccentric phase) in January=green line, July=yellow line, September=orange line and mean for team ( $n=15$ players, Everton FC first team, pre-season values)=black dashed line. Lower panel; the values within each square are the player's percentile scores for selected CMJ variables in January, July and September (relative to normative values derived from pre-season first team CMJ evaluation). Percentage values between squares are the difference \%-wise between the player's performance in Jan (pre-injury) for each variable and his performance in July or September. The variables with left and right values show \% asymmetry at each timepoint with an arrow pointing to the direction of dominance (right or left). CMJ, countermovement jump; Con, concentric; Decel, deceleration; Ecc., eccentric; FT:CT, flight time:contraction time, GRF, ground reaction force; RFD, rate of force development. Force platforms (ForceDecks, Vald Performance, Brisbane, Australia). 


\section{CONCLUSION}

Even for rare injuries such as tibia-fibula fractures, successful RTS is achieved through balancing objective information, utilising specific outcome measures and informed clinical reasoning. ${ }^{13}$ Good communication between performance and sports medical teams facilitates the shared decision-making process, ${ }^{14}$ providing the player with optimal care through integrated performance and health management.

\section{Author affiliations}

${ }^{1}$ Performance Department, Everton Football Club, Liverpool, UK

${ }^{2}$ School of Sport and Exercise Sciences, Liverpool John Moores University,

Liverpool, UK

${ }^{3}$ Aspetar Orthopaedic and Sports Medicine Hospital, Doha, Qatar

${ }^{4}$ Arsenal Performance and Research Team, Arsenal Football Club, London, UK

${ }^{5}$ Sports Surgery Clinic, Dublin, Ireland

${ }^{6}$ University of Roehampton, London, UK

${ }^{7}$ Medical Department, Everton Football Club, Liverpool, UK

${ }^{8}$ Trauma and Orthopaedic Department, Aintree University Hospitals NHS Foundation Trust, Liverpool, UK

${ }^{9}$ University of Santander (UDES), Bucaramanga, Colombia

${ }^{10}$ Simon Bolivar University, Barranquilla, Colombia

Twitter Matt Taberner @MattTaberner, Nicol van Dyk @NicolvanDyk, Tom Allen @ tallen_5, Chris Richter @ChrisRichterPhD and Daniel D Cohen @danielcohen1971

Acknowledgements Alan McCall provided useful feedback on the manuscript.

Contributors SS surgically operated on the player, $\mathrm{CH}$ led early physiotherapy management, MT led physical preparation, planned and wrote the manuscript, NVD, DDC and TA provided guidance and assisted in the writing of the manuscript. CR provided analysis of S\&C diagnostics.

Funding The authors have not declared a specific grant for this research from any funding agency in the public, commercial or not-for-profit sectors.

Competing interests DC consults to a company that sells strength and power diagnostic equipment.

Patient consent for publication Obtained.

Provenance and peer review Not commissioned; externally peer reviewed.

Open access This is an open access article distributed in accordance with the Creative Commons Attribution Non Commercial (CC BY-NC 4.0) license, which permits others to distribute, remix, adapt, build upon this work non-commercially, and license their derivative works on different terms, provided the original work is properly cited, appropriate credit is given, any changes made indicated, and the use is non-commercial. See: http://creativecommons.org/licenses/by-nc/4.0/.

\section{ORCID iDs}

Matt Taberner http://orcid.org/0000-0003-3465-833X

Nicol van Dyk http://orcid.org/0000-0002-0724-5997

Tom Allen https://orcid.org/0000-0001-6286-7433

Chris Richter https://orcid.org/0000-0001-6017-1520

Daniel D Cohen https://orcid.org/0000-0002-0899-4623

\section{REFERENCES}

1 Ekstrand J, Waldén M, Hägglund M. Hamstring injuries have increased by $4 \%$ annually in men's professional football, since 2001 : a 13-year longitudinal analysis of the UEFA Elite Club injury study. $\mathrm{Br}$ J Sports Med 2016;50:731-7.

2 Boden BP, Lohnes JH, Nunley JA, et al. Tibia and fibula fractures in soccer players. Knee Surg Sports Traumatol Arthrosc 1999;7:262-6.

3 Robertson GAJ, Wood A. Fractures in sport: optimising their management and outcome. World J Orthop 2015;6:850-63.

4. Taberner M, Allen T, Cohen DD. Progressing rehabilitation after injury: consider the 'control-chaos continuum'. Br J Sports Med 2019;53:1132-6.

5 Glasgow P, Phillips N, Bleakley C. Optimal loading: key variables and mechanisms. Br J Sports Med 2015;49:278-9.

6 Robling AG, Turner $\mathrm{CH}$. Mechanical signaling for bone modeling and remodeling. Crit Rev Eukar Gene Expr 2009;19:319-38.

7 Turner $\mathrm{CH}$. Three rules for bone adaptation to mechanical stimuli. Bone 1998:23:399-407.

8 Bemben DA, Palmer IJ, Abe T, et al. Effects of a single bout of low intensity KAATSU resistance training on markers of bone turnover in young men. Int J KAATSU Taining Res 2007;3:21-6.

9 Milgrom Cet al. Do high impact exercises produce higher tibial strains than running? Br J Sports Med 2000;34:195-9.

10 Handford C, Davids K, Bennett S, et al. Skill acquisition in sport: some applications of an evolving practice ecology. J Sports Sci 1997; 15:621-40.

11 Warden SJ. Breaking the rules for bone adaptation to mechanical loading. J Appl Physiol 2006;100:1441-2.

12 Hart LM, Cohen DD, Patterson SD, et al. Previous injury is associated with heightened countermovement jump force-time asymmetries in professional soccer player. Trans/ Sports Med 2019;00:1-7.

13 McCall A, Lewin C, O'Driscoll G, et al. Return to play: the challenge of balancing research and practice. Br J Sports Med 2017;51:702-3.

14 Dijkstra HP, Pollock N, Chakraverty R, et al. Return to play in elite sport: a shared decision-making process. Br J Sports Med 2017;51:419-20. 